\title{
PRODUCTION COST OPERATION OF SOME USED MACHINES DURING THE CONSTRUCTION WORKS IN THE REPUBLIC OF BENIN
}

\section{QUIRIN ENGELBERT AYEDITAN ALAYE ${ }^{1,2}$ and HADILOU MICHEL ALAYE ${ }^{3}$}

${ }^{1}$ Department of Civil Engineering

Harbin Institute of Technology

Harbin 150001

P. R. China

2Department of Civil Engineering

University of Abomey-Calavi

01 BP 2009 Cotonou

Republic of Benin

e-mail: alaye47@yahoo.fr

${ }^{3}$ Ministry of Public Works and Transport

01 BP 351 Cotonou

Republic of Benin

Keywords and phrases: theoretical production, pratical machine production, cost of operating machines, choice of correction coefficients.

Received February 15, 2021

(C) 2021 Scientific Advances Publishers

This work is licensed under the Creative Commons Attribution International License (CC BY 3.0).

http://creativecommons.org/licenses/by/3.0/deed.en_US

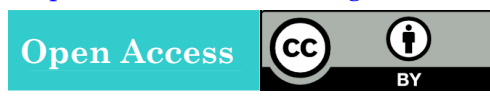




\begin{abstract}
The aim of this research is to determine appropriate correction coefficient of production machine to be considered during the construction of pavement in Republic of Benin. Given that reliable construction project should be in accordance with appropriate services and workmanship, this research proposes a method to be followed for the choice of machines according to the nomenclature of all the tasks necessary for the construction of a pavement. Then, a method for determining the actual production of machinery to be used on the job site while listing some factors to consider in determining prices. Based on the maximum theoretical production of the machines used during construction works, this research shows that improving the soil's performance depends on the quality and the machines' performance. Additionally, the results show that, the machines' theoretical productions must be corrected by appropriate factors linked to the conditions under which the works will be executed. Consequently, for a reassuring determination of the machines' operating cost, this research proposes that the machines to be used will work under challenging conditions.
\end{abstract}

\title{
1. Introduction
}

Reliable construction project should be in accordance with appropriate services and workmanship. Best results must be a key and permanent target for those who are in charge of expenditures of constructed facilities. There are some key factors that compulsory contribute to lower costs such as: material handling, shop installation, inventory. Over decades, new machines and methods have great impact on technologies which reasonably have kicked out of the system of construction companies and associations who are now obsolete [1]. Analysing construction technologies, they have varieties and vague schemes. And the introduction of machines into construction technology at the beginning of the twentieth century keeps most of techniques and materials unchanged. The Table 1 displays details [2]. 
Table 1. Machine required per task or per workstation [2]

\begin{tabular}{|c|c|}
\hline Designation & Necessary machinery \\
\hline Site installation & $\begin{array}{l}\text { Machine carrier, light vehicle, bull, grader, truck } \\
\text { crane. truck }\end{array}$ \\
\hline \multicolumn{2}{|l|}{ Preliminary activities } \\
\hline Woodcut & Bull, grader \\
\hline Clearance of right of way & Bull, grader \\
\hline Demolition of structure & Bull, mechanical or hydraulic excavator \\
\hline Scouring & Bull \\
\hline \multicolumn{2}{|l|}{ Earthworks and pavement works } \\
\hline Excavation in loose soil & Bull, loader, grader, dump truck \\
\hline $\begin{array}{l}\text { Embankments from cuttings or } \\
\text { Embankments from borrowings }\end{array}$ & $\begin{array}{l}\text { Bull, loader, dump truck, water tank truck, } \\
\text { grader, compactor, motor pump }\end{array}$ \\
\hline $\begin{array}{l}\text { Purging poor quality land and } \\
\text { alternative materials }\end{array}$ & $\begin{array}{l}\text { Bull, Chargeuse, Pelle hydraulique, dump truck, } \\
\text { loader, compactor, water tank truck }\end{array}$ \\
\hline Ditches & Grader, bull \\
\hline Rock excavation & $\begin{array}{l}\text { Bull, compressor }+ \text { jackhammer, hydraulic } \\
\text { shovel + rock breaker }\end{array}$ \\
\hline Surface layer & $\begin{array}{l}\text { Bull, loader, grader, compactor, dump truck, } \\
\text { water tank truck, moto-pompe }\end{array}$ \\
\hline \multicolumn{2}{|l|}{ Workstation } \\
\hline $\begin{array}{l}\text { Construction of pavements and } \\
\text { various works }\end{array}$ & $\begin{array}{l}\text { Cement mixer, truck crane, dump truck, hand } \\
\text { compactor, water tank truck, vibrator, motor } \\
\text { pump }\end{array}$ \\
\hline
\end{tabular}

Opposite of what is previously said about big project, it's necessary to highlight the progressive changes $\sim$ innovations in traditional materials and practices. Bricklaying for instance maintains the traditional way of putting one on another. Meanwhile masonry has wonderful development of its technology. Masonry uses tipper trucks, mortar mixers, sophisticated scaffolding systems, motorized wheelbarrows, forklift trucks, new epoxy mortars which provide better adhesion between bricks [3]. Masonry, in addition to the above innovations, will likely use robotic bricklaying. Many other technical changes are being carried out on masonry technology even though they are very slow [4]. 
Knowing the quantity of work, contractors and owners have to be realistic, they must take into account the knowledge of the maximum theoretical production of each machine. This theoretical production is often mentioned in catalogs or technical sheets by machine builders. The theoreticals productions of the machines are provided by catalogs established on the database which do not correspond to the real conditions of the sites [5].

The maximum theoretical production is calculated under the ideal working conditions by the manufacturer $[5,6]$. The machine is supposed to work full time (60 min per hour), that is to say that no waiting time for the driver and no delay are taken into account. These manufacturers provide inputs, according to the available power of the machines, the values of their maximum theoretical productions per task on graphs or charts. Consequently, these theoretical productions must be corrected by appropriate factors linked to the conditions under which the work will be carried out.

Several brands of machines exist and these different machines are manufactured according to the standards in force, they have characteristics which allow the user to classify them or to make the comparison. For example, knowledge of the power and the theoretical production of the caterpillar D6 bulldozer allows to find the approximate theoretical production of a Komatsu or Fiat-Allis bulldozer according to its power.

In this chapter the Caterpillar brand was opted for in the search for the theoretical production of machines. This option is due to the fact that the caterpillar brand is the most used in studied areas by companies.

The document entitled "Caterpillar equipment and method edition October 31, 2000" [7] was used and allowed to obtain different road tasks, towards the theoretical production of Caterpillar brand machines. 


\section{Methodology}

\subsection{Theoretical production of bulldozers caterpillar by task}

\subsubsection{Theoretical production for tree felling}

The diameter at the base of the trunk and the species of trees to be felled affected the condition of the theoretical production of bulldozers [6]. It should be noted that in the method of evaluating road works, only the felling of trees with a circumference greater than $1.5 \mathrm{~m}$ (diameter greater than or equal to $50 \mathrm{~cm}$ ) measured at $1 \mathrm{~m}$ from the ground is remunerated [6]. All other trees below this circumference are classified as shrubs [6]. The felling times of a tree according to the diameter by new bulldozers, the blade perfectly adjusted, working under ideal conditions are listed in Table 2.

Table 2. Time in minutes to fell a tree

\begin{tabular}{ccccc}
\hline & & \multicolumn{3}{c}{ Time (M) in minutes to fell a tree by diameter } \\
Bulldozers & Available power & \multicolumn{3}{c}{ category (min/tree) } \\
\cline { 3 - 5 } Caterpillar & at the wheel & $\mathrm{M}_{1}$ for & $\mathrm{M}_{2}$ for & $\mathrm{M}_{3}$ for \\
& & $\begin{array}{c}\text { diameter from } \\
60 \text { to } 90 \mathrm{~cm}\end{array}$ & $\begin{array}{c}\text { diameter from } \\
90 \text { to } 120 \mathrm{~cm}\end{array}$ & $\begin{array}{c}\text { diameter from } \\
120 \text { to 180cm }\end{array}$ \\
\hline D6R & 123KW (165HP) & 3.4 & 6.8 & $\begin{array}{c}\text { Insufficient power } \\
\text { for slaughter }\end{array}$ \\
D7R & 171KW (230HP) & 1.7 & 3.3 & 10.2 \\
D8R & $228 \mathrm{KW}(305 \mathrm{HP})$ & 1.3 & 2.2 & 6 \\
D9R & $302 \mathrm{KW}(405 \mathrm{HP})$ & 0.4 & 1.3 & 3 \\
\hline
\end{tabular}

$\mathrm{KW}=$ Kilowatt, $\mathrm{HP}=$ Horsepower, $1 \mathrm{KW}=1.341 \mathrm{HP}=1.36 \mathrm{CV}$.

The time $(T)$ per hectare takes into account the number $(\mathrm{N})$ of trees per hectare in each diameter category, obtained during the field study as shown in Equation (1) [6].

$$
T=\alpha\left(M_{1} \times N_{1}+M_{2} \times N_{2}+M_{3} \times N_{3}\right),
$$

where $T$ is time per hectare in minutes and $\alpha$ is percentage of hardwoods. 
According to caterpillar, the percentage of hardwoods encountered in the field affects the total time $T$ as follows:

75 to $100 \%$ : add $30 \%$ to the total time $(\alpha=1.3)$,

25 to $75 \%$ : unchanged $(\alpha=1)$,

0 to $25 \%$ : subtract $30 \%$ from the total time $(\alpha=0.7)$.

$M_{1}$ is the time in minutes per tree in each diameter category; $N$ is the number of trees per hectare, in each diameter category obtained during the field study.

\subsubsection{Theoretical production for stripping or clearing work making right of way without cutting down large trees}

Theoretical production for these kinds of works largely depends part of the environment [6, 7]. The environmental factors that affect production are: density of vegetation, climbing plants, undergrowth, type of surface soil and so on.

The theoretical production of caterpillar bulldozers according to their power, to the type of vegetation and the ideal working conditions $[6,7]$ is mentioned in the Table 3. In this Table 3, all shrubs are considered to be vegetation and, the base time per hectare mentioned is established for average vegetation. 
Table 3. Time in minutes for stripping work or clearing of right-of-way

\begin{tabular}{|c|c|c|c|c|c|}
\hline \multirow{3}{*}{$\begin{array}{l}\text { Caterpillar } \\
\text { bulldozers }\end{array}$} & \multirow{3}{*}{$\begin{array}{c}\text { Available } \\
\text { power at the } \\
\text { wheel }\end{array}$} & \multirow{3}{*}{$\begin{array}{l}\text { Basic time } \\
\text { per hectare } \\
\text { in minutes }\end{array}$} & \multicolumn{3}{|c|}{$\begin{array}{c}\text { Time in minutes to cover one hectare of land } \\
\text { depending on the vegetation }\end{array}$} \\
\hline & & & $\begin{array}{c}\text { Sparse } \\
\text { vegetation } \\
\text { (Less than } 990 \\
\text { shrubs/ha) }\end{array}$ & $\begin{array}{c}\text { Average } \\
\text { vegetation } \\
\text { (990 to } 1480 \\
\text { shrubs/ha) }\end{array}$ & $\begin{array}{c}\text { Dense } \\
\text { vegetation } \\
\text { (more than } \\
1480 \\
\text { shrubs/ha) }\end{array}$ \\
\hline & & & $\begin{array}{c}\text { Corrective } \\
\text { coefficient: } 0.7\end{array}$ & $\begin{array}{l}\text { Corrective } \\
\text { coefficient: } 1\end{array}$ & $\begin{array}{l}\text { Corrective } \\
\text { coefficient: } 2\end{array}$ \\
\hline D6R & $123 \mathrm{KW}$ & 85 & $85 \times 0.7 \approx 60$ & $85 \times 1=85$ & $85 \times 2=170$ \\
\hline D7R & $171 \mathrm{KW}$ & 58 & $58 \times 0.7 \approx 41$ & $58 \times 1=58$ & $58 \times 2=116$ \\
\hline D8R & $228 \mathrm{KW}$ & 45 & $45 \times 0.7 \approx 32$ & $45 \times 1=45$ & $45 \times 2=90$ \\
\hline D9R & $302 \mathrm{KW}$ & 39 & $39 \times 0.7 \approx 28$ & $39 \times 1=39$ & $39 \times 2=78$ \\
\hline
\end{tabular}

Clearance of the right-of-way for roadworks requires also, in this same operation, the evacuation of the products out of the cleared area. In this case, caterpillar recommends increasing by $50 \%$ the time mentioned in this Table 3.

From the elements in this Table 3, the theoretical hourly production of a given Bulldozer will be deducted according to the type of vegetation. Thus, for the clearance of the right-of-way within the framework of road works (time to be increased by 50\%), a caterpillar D6R bulldozer in medium vegetation will do a time $T=1.5 \times 85 \mathrm{~min} / \mathrm{ha}=128 \mathrm{~min} / \mathrm{ha}$. This, gives a theoretical hourly production equal to $60 \mathrm{~min} / T=60 / 128 \mathrm{ha}=$ $0.47 \mathrm{ha}$. Under the same conditions, the theoretical hourly production of a caterpillar D7R is equal to 0.68ha. It follows that a bad appreciation of the vegetation in the area to treat, will have enormous consequences on the execution of the work.

In order to reduce the risk of errors, a preliminary study is necessary to recognize the type of vegetation (dense, medium or sparse) as shown by [5]. For this purpose, it will be necessary to traverse the zone concerned to determine the surface covered by each type of vegetation and to carry 
out at least three quantitative surveys of shrubs in each zone. These counts are made by taking two points spaced $100 \mathrm{~m}$ apart. The vegetation is counted and measured along the line connecting these two points over a width of approximately $5 \mathrm{~m}$ from each side. This gives the quantity of shrubs on 1/10ha. This simple method has its shortcomings. However, if the sampling is carefully done, these shortcomings are minimized and the result much more realistic.

\subsubsection{Theoretical production for earthworks}

Most materials are moved with bulldozers. However, theoretical production depends on the following characteristics: the power of the machine; the type and the capacity of the blade; the duration of the cycle; and the density of the material to be moved [8,9]. Thus, Equation (2) is used to calculate the theoretical production.

$$
P_{T}=B_{C} \times N_{C}
$$

where $P_{T}$ is the theoretical production $\left(\mathrm{m}^{3} / \mathrm{h}\right) ; B_{C}$ is the blade capacity; $N_{C}$ is the number of cycles per hour.

For the type of blade, it is important to specify that the blade here is the dozer placed in front of the bulldozer, to allow the delivery of materials. The lower part of this blade is in contact with the soil during work. These lower parts are fixed with bolts, metal plates which are also called wear blades or sharp edges. The cant cylinders mounted today on the dozer's arms increase the productivity and versatility of these bulldozers. Thus, along the pivot axis of the blade, following the operation of tilt cylinders, a bulldozer can also be a tiltdozer or a tipdozer. It takes the name of angledozer when the blade can be oriented obliquely to the direction of travel. Depending on the type of bulldozer and its variants, several blades or dozers were manufactured. The Tables 4 and 5 show the working speed of some caterpillar bulldozers [6]. These working speeds make it possible to calculate the theoretical production per linear meter, or kilometer of the creation of ditches by dividing them, by the number of 
passes of blades or rippers. Taking into account all the technical data, the calculation formula and the theoretical production, the production for earthworks has been established and shown in Table 6 . The results in this table relate to the earthworks of the abundant dry earth with a dry volumic mass of $1300 \mathrm{~kg} / \mathrm{m}^{3}$. When it comes to clay, gravel or other, it will be necessary to multiply the results of this table by the correction coefficient 1300/w. w being the density of the material to be earthed such as show in Table 7.

Table 4. Working speed of some caterpillar bulldozers

\begin{tabular}{ccccccc}
\hline $\begin{array}{c}\text { Caterpillar } \\
\text { bulldozers }\end{array}$ & D6R & D7R & D7G & D8R & D9R & D10R \\
\hline $\begin{array}{c}\text { First speed } \\
\text { (To go) }\end{array}$ & $3.9 \mathrm{~km} / \mathrm{h}$ & $3.7 \mathrm{~km} / \mathrm{h}$ & $3.7 \mathrm{~km} / \mathrm{h}$ & $3.5 \mathrm{~km} / \mathrm{h}$ & $4 \mathrm{~km} / \mathrm{h}$ & $4 \mathrm{~km} / \mathrm{h}$ \\
$\begin{array}{c}\text { Second speed } \\
\text { (on the return) }\end{array}$ & $8.7 \mathrm{~km} / \mathrm{h}$ & $8.3 \mathrm{~km} / \mathrm{h}$ & $7.9 \mathrm{~km} / \mathrm{h}$ & $8.1 \mathrm{~km} / \mathrm{h}$ & $8.4 \mathrm{~km} / \mathrm{h}$ & $8.9 \mathrm{~km} / \mathrm{h}$ \\
\hline
\end{tabular}

Table 5. Number of cycles per hour according to the average cycle time per distance

\begin{tabular}{cccccccc}
\hline Distance & $15 \mathrm{~m}$ & $30 \mathrm{~m}$ & $50 \mathrm{~m}$ & $60 \mathrm{~m}$ & $100 \mathrm{~m}$ & $120 \mathrm{~m}$ & $150 \mathrm{~m}$ \\
\hline Number of cycles & 100 & 60 & 35 & 30 & 16 & 14 & 12 \\
\hline
\end{tabular}


Table 6. Theoretical production of bulldozers for earthworks according to the type of blade

\begin{tabular}{|c|c|c|c|c|c|c|c|c|c|c|}
\hline \multirow[t]{2}{*}{$\begin{array}{l}\text { Caterpillar } \\
\text { bulldozers }\end{array}$} & \multirow[t]{2}{*}{$\begin{array}{c}\text { Available } \\
\text { power at } \\
\text { the } \\
\text { wheel }\end{array}$} & \multirow[t]{2}{*}{$\begin{array}{c}\text { Blade } \\
\text { type }\end{array}$} & \multirow[t]{2}{*}{$\begin{array}{c}\text { Blade } \\
\text { capacity } \\
\left(\mathrm{m}^{3}\right)\end{array}$} & \multicolumn{7}{|c|}{$\begin{array}{l}\text { Production in } \mathrm{m}^{3} / \mathrm{h} \text { of abundant material with } \\
\text { density } 1300 \mathrm{~kg} / \mathrm{m}^{3} \text {, depending on the delivery } \\
\text { distance in meters }\end{array}$} \\
\hline & & & & $15 \mathrm{~m}$ & $30 \mathrm{~m}$ & $50 \mathrm{~m}$ & $60 \mathrm{~m}$ & $100 \mathrm{~m}$ & $120 \mathrm{~m}$ & $150 \mathrm{~m}$ \\
\hline \multirow{3}{*}{ D6R } & \multirow{3}{*}{$\begin{array}{l}123 \mathrm{KW} \\
(165 \mathrm{HP})\end{array}$} & $\mathrm{U}$ & - & - & - & - & - & - & - & - \\
\hline & & SU & 5.62 & 562 & 337 & 196 & 168 & 90 & 78 & 67 \\
\hline & & $\mathrm{S}$ & 3.70 & 370 & 222 & 129 & 111 & 59 & 51 & 44 \\
\hline \multirow{3}{*}{ D7G } & \multirow{3}{*}{$\begin{array}{l}149 \mathrm{KW} \\
(200 \mathrm{HP})\end{array}$} & $\mathrm{U}$ & 6.70 & 670 & 402 & 234 & 201 & 107 & 93 & 80 \\
\hline & & SU & - & - & - & - & - & - & - & - \\
\hline & & $\mathrm{S}$ & 4.20 & 420 & 252 & 147 & 126 & 67 & 58 & 50 \\
\hline \multirow{3}{*}{ D7R } & \multirow{3}{*}{$\begin{array}{l}171 \mathrm{KW} \\
(230 \mathrm{HP})\end{array}$} & $\mathrm{U}$ & 8.34 & 834 & 500 & 291 & 250 & 133 & 116 & 100 \\
\hline & & $\mathrm{SU}$ & 6.86 & 686 & 411 & 240 & 205 & 109 & 96 & 82 \\
\hline & & $\mathrm{S}$ & 5.16 & 516 & 309 & 180 & 154 & 82 & 72 & 61 \\
\hline \multirow{3}{*}{ D8R } & \multirow{3}{*}{$\begin{array}{l}228 \mathrm{KW} \\
(305 \mathrm{HP})\end{array}$} & $\mathrm{U}$ & 11.70 & 1170 & 702 & 409 & 351 & 187 & 163 & 140 \\
\hline & & $\mathrm{SU}$ & 8.68 & 868 & 520 & 303 & 260 & 138 & 121 & 104 \\
\hline & & $\mathrm{S}$ & - & - & - & - & - & - & - & - \\
\hline \multirow{3}{*}{ D9R } & \multirow{3}{*}{$\begin{array}{l}302 \mathrm{KW} \\
(405 \mathrm{HP})\end{array}$} & $\mathrm{U}$ & 16.40 & 1640 & 984 & 574 & 492 & 262 & 229 & 196 \\
\hline & & $\mathrm{SU}$ & 13.50 & 1350 & 810 & 472 & 405 & 216 & 189 & 162 \\
\hline & & $\mathrm{S}$ & - & - & - & - & - & - & - & - \\
\hline
\end{tabular}


Table 7. Average volumic mass values of some types of soil

\begin{tabular}{lcc}
\hline \multirow{2}{*}{ Type of soil } & \multicolumn{2}{c}{ Volumic mass $\left(\mathrm{kg} / \mathrm{m}^{3}\right)$} \\
\cline { 2 - 3 } Dry clay & Natural, in place & Loose, abundant \\
Wet clay & 1600 & 1200 \\
Dry earth & 2200 & 1600 \\
Wet earth & 1600 & 1300 \\
Dry gravel & 2000 & 1600 \\
Wet gravel & 1800 & 1600 \\
Dry sand & 2200 & 1900 \\
Wet sand & 1600 & 1400 \\
Limestone rock & 2100 & 1900 \\
Gypsum rock & 2600 & 1500 \\
\hline
\end{tabular}

For example, if these last two tables (Tables 6 and 7) are taken into account, the theoretical production for earthmoving or stacking at the limestone rock quarry with a D6R blade bulldozer (SU) over an average delivery distance of $50 \mathrm{~m}$ is equal to $196 \times 1300 / 2600=98 \mathrm{~m}^{3} / \mathrm{h}$.

\subsubsection{Theoretical production for rocket work or smashing the rock}

Powerful bulldozers equipped with single-tooth rippers, today make it possible to disaggregate several categories of rock which formerly required blasting [6]. If necessary, a preliminary backfiring allows to fragment the material and allow good penetration of the ripper tooth. Theoretical production for rocket or smashing the rock depends on the hardness of the rock to be fragmented [6]. This hardness is determined using seismographs with refractions that measure the speed of sound in the ground. At a seismic speed not exceeding $3000 \mathrm{~m} / \mathrm{s}$, the rocks are practically knocked off by bulldozer rippers. Above $3000 \mathrm{~m} / \mathrm{s}$ their blasting is essential [6]. For a better cleanup with bulldozers, it is better to use those with a power greater than or equal to $228 \mathrm{KW}(305 \mathrm{HP})[6,10]$. 
Tables 8 and 9 show the seismic speed limit for each type of bulldozer and their hourly theoretical production.

Table 8. Seismic speed limit for each bulldozer

\begin{tabular}{lcc}
\hline $\begin{array}{c}\text { Bulldozers equipped } \\
\text { with ripper }\end{array}$ & $\begin{array}{c}\text { Available power at the } \\
\text { wheel }\end{array}$ & $\begin{array}{c}\text { Seismic speed above which } \\
\text { rocket work is impossible }\end{array}$ \\
\hline D8R & $228 \mathrm{KW}(305 \mathrm{HP})$ & $2000 \mathrm{~m} / \mathrm{s}$ \\
D9R & $302 \mathrm{KW}(405 \mathrm{HP})$ & $2500 \mathrm{~m} / \mathrm{s}$ \\
D10R & $425 \mathrm{KW}(570 \mathrm{HP})$ & $2700 \mathrm{~m} / \mathrm{s}$ \\
D11R & $634 \mathrm{KW}(850 \mathrm{HP})$ & $3000 \mathrm{~m} / \mathrm{s}$ \\
\hline
\end{tabular}

Table 9. Hourly theoretical production of fragmented rock

\begin{tabular}{|c|c|c|c|c|c|c|c|c|c|}
\hline \multirow{2}{*}{$\begin{array}{l}\text { Bulldozers } \\
\text { with single- } \\
\text { tooth rippers }\end{array}$} & \multirow{2}{*}{$\begin{array}{c}\text { Power } \\
(\mathrm{KW})\end{array}$} & \multicolumn{8}{|c|}{$\begin{array}{l}\text { Theoretical production in } \mathrm{m}^{3} / \mathrm{h} \text { of fragmented rock } \\
\text { according to the seismic speed }\end{array}$} \\
\hline & & $\begin{array}{c}800 \\
(\mathrm{~m} / \mathrm{s})\end{array}$ & $\begin{array}{l}1000 \\
(\mathrm{~m} / \mathrm{s})\end{array}$ & $\begin{array}{l}1250 \\
(\mathrm{~m} / \mathrm{s})\end{array}$ & $\begin{array}{l}1500 \\
(\mathrm{~m} / \mathrm{s})\end{array}$ & $\begin{array}{l}1700 \\
(\mathrm{~m} / \mathrm{s})\end{array}$ & $\begin{array}{l}2000 \\
(\mathrm{~m} / \mathrm{s})\end{array}$ & $\begin{array}{l}2500 \\
(\mathrm{~m} / \mathrm{s})\end{array}$ & $\begin{array}{l}2700 \\
(\mathrm{~m} / \mathrm{s})\end{array}$ \\
\hline D8R & 228 & 1700 & 1500 & 1250 & 950 & 750 & 500 & - & - \\
\hline D9R & 302 & 1900 & 1700 & 1300 & 1100 & 900 & 600 & 250 & - \\
\hline D10R & 425 & 2300 & 2100 & 1750 & 1350 & 1100 & 750 & 350 & - \\
\hline
\end{tabular}

Unfortunately, the information received at the office of Geological and Mining Research prove the nonexistence of a seismograph in the study area. This is why the contractors use the means available to them for the cleanup work. So, it can be concluded that, certain accurate machines are lacking during construction projects. This situation can result in bad construction despite the good quality of the pavement materials. 


\subsubsection{Theoretical production of graders by task}

\subsubsection{Theoretical production for preparatory work for the Subgrade, the implementation of the wearing course and the cleaning of the area}

The production corresponds to the surface cleaned or worked per hour $[6,10]$. This production is calculated by multiplying the working speed by the effective cutting width of the blade as shown in Equation (3).

$$
P_{T}=L_{C} \times s / 10,
$$

where $P_{T}$ is the theoretical production (ha/h); $L_{C}$ is width of the cut (m); $s$ is the speed $(\mathrm{km} / \mathrm{h})$.

As the shield which carries the blade is generally oblique during the movement of the material, the actual width of material swept by the shield corresponding to the effective width of cut of the blade is a function of the angle of inclination $\alpha$ expressed in degrees as shown in Equation (4).

$$
L_{C}=L_{B} \times \sin \alpha,
$$

where, $L_{C}$ is width of the cut $(\mathrm{m}) ; L_{B}$ is length of the blade; $\alpha$ is the angle between the front frame and the front point of the shield.

As for the working speed, it should be noted that for all work intensive with machines, the first forward speed is the recommended working speed because working at low speed reduces wear and breakage of certain parts and prolongs the service life of the machine. Only light reprofiling can be done using the second speed.

Table 10 gives the theoretical production of graders caterpillar for the cleaning of the area, the preparation of the platform and the implementation of the wearing course with the blade tilted at 60 degrees. 
Table 10. Hourly theoretical production of caterpillar graders commonly for cleaning the area with a blade pass

\begin{tabular}{cccccc}
\hline $\begin{array}{c}\text { Caterpillar } \\
\text { grader model }\end{array}$ & $\begin{array}{c}\text { Power at } \\
\text { the wheel }\end{array}$ & $\begin{array}{c}\text { Blade or } \\
\text { shield } \\
\text { length }(\mathrm{m})\end{array}$ & $\begin{array}{c}\text { Effective blade } \\
\text { cutting width } \\
\text { for an angle of } \\
\text { 60 degrees }(\mathrm{m})\end{array}$ & $\begin{array}{c}\text { Working } \\
\text { speed: First } \\
\text { forward } \\
\text { speed (m) }\end{array}$ & $\begin{array}{c}\text { Production } \\
\text { (ha/h) }\end{array}$ \\
\hline $120 \mathrm{G}$ & $\begin{array}{c}93 \mathrm{KW} \\
(125 \mathrm{HP})\end{array}$ & 3.66 & 3.17 & 3.9 & 1.2 \\
$120 \mathrm{~B}$ & $\begin{array}{c}93 \mathrm{KW} \\
(125 \mathrm{HP})\end{array}$ & 3.66 & 3.17 & 4.2 & 1.3 \\
$130 \mathrm{G}$ & $\begin{array}{c}101 \mathrm{KW} \\
(135 \mathrm{HP})\end{array}$ & 3.65 & 3.17 & 3.7 & 1.1 \\
$140 \mathrm{G}$ & $\begin{array}{c}112 \mathrm{KW} \\
(150 \mathrm{HP})\end{array}$ & 3.66 & 3.17 & 3.9 & 1.2 \\
$12 \mathrm{G}$ & $\begin{array}{l}101 \mathrm{KW} \\
(135 \mathrm{HP})\end{array}$ & 3.67 & 3.17 & 3.7 & 1.3 \\
\hline
\end{tabular}

\subsubsection{Theoretical production for reprofiling work, creation and cleaning of ditches and so on}

Theoretical production corresponds to the number of linear kilometers of reprofiled pavement, implemented platform or created ditches [6, 10]. This production is a function of the average speed of the grader and the number of passes of the blade as shown in Equation (5).

$$
P_{T}=s \times N_{P},
$$

where $P_{T}$ is the theoretical production $(\mathrm{km} / \mathrm{h}) ; s$ is average speed $(\mathrm{km} / \mathrm{h})$, $N_{P}$ is number of passes.

Light reshaping work can be done with first speed or second speed with three (3) regulatory passes on a 5 to $7 \mathrm{~m}$ pavement, while the other aforementioned work must be done at first speed with a number of passes which takes into account the nature of the soil [6]. Table 11 shows the Hourly theoretical production of caterpillar graders commonly used in the study area for the reshaping of a 5 to $7 \mathrm{~m}$ pavement. 
Table 11. Hourly theoretical production of caterpillar graders commonly used for the reshaping of a 5 to $7 \mathrm{~m}$ pavement

\begin{tabular}{ccccccc}
\hline $\begin{array}{c}\text { Caterpillar } \\
\text { grader } \\
\text { model }\end{array}$ & $\begin{array}{c}\text { Power at } \\
\text { the wheel }\end{array}$ & $\begin{array}{c}\text { First } \\
\text { speed } \\
(\mathrm{km} / \mathrm{h})\end{array}$ & $\begin{array}{c}\text { Second } \\
\text { speed } \\
(\mathrm{km} / \mathrm{h})\end{array}$ & $\begin{array}{c}\text { Average } \\
\text { speed } \\
(\mathrm{km} / \mathrm{h})\end{array}$ & $\begin{array}{c}\text { Number of } \\
\text { blade passes }\end{array}$ & $\begin{array}{c}\text { Hourly } \\
\text { production } \\
(\mathrm{km} / \mathrm{h})\end{array}$ \\
\hline $120 \mathrm{G}$ & $\begin{array}{c}93 \mathrm{KW} \\
(125 \mathrm{HP})\end{array}$ & 3.9 & 6.2 & 5 & 3 & $5 / 3=1.6$ \\
$120 \mathrm{~B}$ & $\begin{array}{c}93 \mathrm{KW} \\
(125 \mathrm{HP})\end{array}$ & 4.2 & 6.4 & 5.3 & 3 & $5.3 / 3=1.7$ \\
$130 \mathrm{G}$ & $\begin{array}{c}101 \mathrm{KW} \\
(135 \mathrm{HP})\end{array}$ & 3.7 & 6 & 4.3 & 3 & $4.3 / 4=1.6$ \\
$140 \mathrm{G}$ & $\begin{array}{c}112 \mathrm{KW} \\
(150 \mathrm{HP})\end{array}$ & 3.9 & 6.3 & 5.1 & 3 & $5.3 / 3=1.7$ \\
$12 \mathrm{G}$ & $\begin{array}{c}101 \mathrm{KW} \\
(135 \mathrm{HP})\end{array}$ & 3.7 & 6 & 4.8 & 3 & $4.8 / 3=1.6$ \\
\hline
\end{tabular}

\subsubsection{Theoretical production of wheel loaders}

The loaders are mainly used for loading and transport of materials over very short distances $[2,6]$. The theoretical production of the loaders is given by tables. This production depends on the capacity of the bucket; cycle time and fill factor [10] as shown in Equation (6).

$$
P_{T}=B_{V} \times \zeta
$$

where $P_{T}$ is the theoretical production $\left(\mathrm{m}^{3} / \mathrm{h}\right) ; B_{V}$ is bucket volume $\left(\mathrm{m}^{3}\right), \zeta$ is fill factor.

Furthermore, the filling factor of the bucket depends on the nature of the material. This coefficient is equal to $100 \%$ when the material to be loaded or to be transported is ordinary soil abundant. In other cases, the filling factor is $95 \%$ for ordinary earth; $85 \%$ for compacted earth; $75 \%$ for well dynamited rock and $60 \%$ for rock block. 
As for the cycle time for a loader, it is equal to the time necessary to load the bucket, turn the machine, move it, empty the contents of the bucket and return the machine to its initial position [6]. This cycle time varies between $0 \mathrm{~min} ; 40 \mathrm{~min}$ and $0.60 \mathrm{~min}$, taking into account the type of material, for wheel loaders (the kind mainly used in the study area for loading material) [10]. This made it possible to find the number of cycles per hour and to establish in Table 12, the theoretical production for abundant material [10].

Table 12. Theoretical production in $\mathrm{m}^{3} / \mathrm{h}$ of abundant lateritic material

\begin{tabular}{|c|c|c|c|c|c|c|c|c|}
\hline \multicolumn{2}{|c|}{ Caterpillar loader model } & 906 & 924 & $928 \mathrm{G}$ & $938 \mathrm{G}$ & $950 \mathrm{G}$ & $966 \mathrm{~F}$ & $970 \mathrm{~F}$ \\
\hline \multicolumn{2}{|c|}{ Bucket volume $\left(\mathrm{m}^{3}\right)$} & 1 & 1.5 & 2 & 2.5 & 3 & 3.5 & 4 \\
\hline $\begin{array}{l}\text { Duration of } \\
\text { cycle (min) }\end{array}$ & $\begin{array}{l}\text { Number of } \\
\text { cycles/hours }\end{array}$ & & & & & & & \\
\hline 0.40 & 150 & 150 & 225 & 300 & 375 & 450 & 525 & - \\
\hline 0.45 & 133 & 133 & 200 & 268 & 332 & 400 & 466 & 530 \\
\hline 0.50 & 120 & 120 & 180 & 240 & 300 & 360 & 420 & 480 \\
\hline 0.55 & 109 & 109 & 164 & 218 & 272 & 328 & 386 & 436 \\
\hline 0.60 & 100 & 100 & 150 & 200 & 250 & 300 & 350 & 400 \\
\hline
\end{tabular}

\subsubsection{Theoretical production of compactors}

The production of compactors is expressed in cubic meters compacted per hour $\left(\mathrm{m}^{3} / \mathrm{h}\right)$ [6]. This production depends on three essential factors which are: soil type, water content and thickness of the layer to be compacted $[6,7]$.

These factors have a direct influence on the number of passes required. Theoretical production is calculated by Equation (7).

$$
P_{T}=L_{w} \times s \times T_{C L} / N
$$

where $P_{T}$ is the theoretical production $\left(\mathrm{m}^{3} / \mathrm{h}\right) ; L_{w}$ is working width at each pass (m) (for compactors with two smooth drums, the working width 
at each pass is twice the width of a drum); $s$ is average speed $(\mathrm{km} / \mathrm{h}), T_{C L}$ is thickness of the compacted layer $(\mathrm{mm}) ; N$ is number of passes required to obtain the desired compaction (can only be determined from a test section).

Compaction equipment is often chosen based on the type of soil [6]. For dirt roads in tropical area such as at the study area, tire compactors and those with smooth or vibrating cylinders are commonly used because they are well suited for compacting lateritic gravels or ordinary soils. Equation (7) is used to determine the results shown in Table 13 for tire compactors commonly used in studied areas.

Table 13. Theoretical production of tire compactors for a single pass $\left(\mathrm{m}^{3} / \mathrm{h}\right)$

\begin{tabular}{cccccccc}
\hline \multirow{2}{*}{$\begin{array}{c}\text { Compactor } \\
\text { of tire }\end{array}$} & \multirow{2}{*}{$\begin{array}{c}\text { Compaction } \\
\text { width }\end{array}$} & \multirow{2}{*}{$\begin{array}{c}\text { Number } \\
\text { of passes }\end{array}$} & $\begin{array}{c}\text { Average } \\
\text { speed }\end{array}$ & \multicolumn{4}{c}{ Thickness of the compacted layer } \\
\cline { 5 - 7 } Ps 150 & & & 6.5 & 1122 & 1684 & 2245 & 2806 \\
and & 1.73 & 1 & 9.5 & 1640 & 2460 & 3280 & 4100 \\
Ps 200 & & & 13 & 2245 & 3367 & 4490 & 5612 \\
& & & 6.5 & 1235 & 1852 & 2470 & 3087 \\
Ps 300 & \multirow{2}{*}{1.9} & 9.5 & 1805 & 2707 & 3610 & 4512 \\
and & & & 13 & 2470 & 3705 & 4940 & 6175 \\
PF 300 & & & 6.5 & 1573 & 2359 & 3146 & 3932 \\
Ps 500 & \multirow{2}{*}{1.42} & 1 & 9.5 & 2299 & 3448 & 4598 & 5747 \\
& & & 13 & 3146 & 4719 & 6292 & 7865 \\
\hline
\end{tabular}

\subsection{Practical machine production}

It is almost impossible for a construction machine to work continuously for 8 hours a day [6,7]. There are always interruptions and unforeseen events due to the operator. The competence of the driver, the working conditions and the organization of the site are the main factors which determine the efficiency of the machines at work [6]. The efficiency 
coefficient depends on the correction coefficient for working conditions, the production correction coefficient due to the operator and the coefficient due to the condition or age of the machine and the organization set up [6]. The practical production of the machines is calculated by Equation (8):

$$
P_{P}=P_{T} \times \alpha_{C}
$$

where $P_{P}$ is Practical production; $P_{T}$ is theoretical production; $\alpha_{C}$ is appropriate correction coefficient.

Since nothing can be done perfectly even in the best-case scenario, it should be noted that it is almost impossible on a construction site to have at the same time an excellent driver, ideal working conditions and excellent organization. This is why, under the favorable working and organizational conditions with an excellent driver, specialists use 0.83 as the efficiency coefficient which is suggested by [6]. This gives an average usage period of 50 minutes per hour. In difficult working conditions, after combination, they retain 0.67 as the efficiency coefficient; or a usage time of 40 minutes per hour which is suggested by [6]. Below this value, it is necessary to review the factors which influence the working efficiency of the machines during the execution of the works.

By this result, a contractor sure of his organization and the means to implement can apply at his risk, a correction coefficient in the range from 0.67 to 0.83 ; which will allow it to be competitive in the market [6].

On the other hand, for a contractor who is taking his first steps in this field, the practical production to be considered in the calculations must be as low as possible [6]. Thus, the correction coefficient for theoretical production must fall outside this range from 0.67 to 0.83 for the following aspects:

(1) At the beginning, most of the equipment will be rented,

(2) the driver has never been tested by the contractor who will rent the machine, 
(3) the condition of the equipment is not known in advance,

(4) Diesel theft cases on site,

(5) The advance that the rental company will claim.

Clearly the young contractor will work in very difficult conditions and he will want to put a profit margin.

For these cases of uncertainty of a beginner contractor, the aspects listed above obliges him to apply a reduction of 0.20 on the correction coefficient 0.67 , which is initially expected in difficult working conditions. Consequently, this contractor finds himself in a safety margin which, once the contract has been obtained, will take all the necessary measures to have a production above $37 \%$ of the theoretical maximum production of the machines whatever the site conditions.

By putting us in the cases of this contractor, all the theoretical maximum productions initially known in the catalog Caterpillar will be brought back to $37 \%$ of their value to find the practical productions to be considered to improve the performance of soil or pavement.

For this case study a practical production of 0.37 was applied to the maximum theoretical production of the machines as shown by Equation (9).

$$
P_{P}=0.37 P_{T}
$$

where $P_{P}$ is practical production; $P_{T}$ is theoretical production.

\subsection{Cost of operating machines using 0.37 as appropriate correction coefficient}

Because of the inability to attach the complete dossier for this study to call for tenders to our case study, the quantitative estimate of this study of call for tenders, making it possible to estimate the operating cost of the equipment necessary for the execution of this work. The machines were chosen according to the role assigned to them. 
After the site visit, and using the data from the call record of offers, a list of the necessary equipment was drawn up in order to deduce, with regard to the fleet, the additional equipment. Thus, rental commitments could be raised from potential rental companies, such as the Public Works equipment company or other companies.

It is important to note that, since the equipment rental prices vary from one company to another and that the prices are charged by the public works equipment Company are representative of the fact that they are close to the average, also practiced by other companies, the contractor may decide to rent the equipment from the latter or even take as a reference the rental rate thereof.

In addition, as for the calculation of the practical production of the machines to be mobilized, knowing that everything is not perfect in the best of all worlds, the contractor will choose a correction coefficient for the theoretical production of the machines ${ }^{[190]}$. In this specific study case, the coefficient 0.37 is used to correct the theoretical productions of the machines to be mobilized. Besides, to determine the hourly consumption the Equation (10) is used.

$$
Z=\frac{Y \times P}{\rho},
$$

where $Z$ is hourly consumption (l); $Y$ is consumption $(\mathrm{g} / \mathrm{CV} / \mathrm{h}) ; P$ is power $(\mathrm{CV}) ; \rho$ is fuel volumic mass $(\mathrm{g} / \mathrm{l})$.

\section{Results and Discussion}

\subsection{Basic fuel consumption of the machines}

The Table 14 shows the basic fuel consumption values of the machines in studied area. It is important to notify that:

(1) The price of a liter of diesel at the pump during the research is 0.63 USD,

(2) Concerning the choice relating to the brand and the type of truck to be used, it is impossible to give in this Table 14, the brand and the type of trucks and vehicle carrier, that mentioned constitutes the average. 
Table 14. Basic fuel consumption values of the machines

\begin{tabular}{|c|c|c|c|}
\hline \multirow[b]{2}{*}{ Material designation } & \multirow{2}{*}{$\begin{array}{l}\text { Power } \\
(\mathrm{CV})\end{array}$} & \multicolumn{2}{|c|}{ Hourly consumption } \\
\hline & & $\begin{array}{c}\text { Volume } \\
\text { (liter) }\end{array}$ & $\begin{array}{l}\text { Price } \\
\text { (USD) }\end{array}$ \\
\hline Bulldozer Cat. D6R & 167 & 29 & 18.14 \\
\hline Bulldozer Cat. D7G & 203 & 35 & 21.89 \\
\hline Bulldozer Cat, D7R & 233 & 41 & 25.64 \\
\hline Grader Car. 12G & 162 & 28 & 17.51 \\
\hline Grader Car. 120B and 120G & 126 & 22 & 13.76 \\
\hline Chargeuse Car. 924 & 126 & 22 & 13.76 \\
\hline Self-propelled compactor PF200 and PF300 & 109 & 19 & 11.88 \\
\hline Hand vibrating compactor & 2 to 3 & 01 & 0.63 \\
\hline Cement mixer (300L) & 2 to 3 & 01 & 0.63 \\
\hline Motor pump $30 \mathrm{~m}^{3} / \mathrm{h}$ & 2 to 3 & 01 & 0.63 \\
\hline Generator & 24 & 04 & 2.50 \\
\hline Machine carrier & & 30 & 18.76 \\
\hline Dump truck 6/7m & & 15 & 9.38 \\
\hline Water tank truck 10/12 & & 15 & 9.38 \\
\hline Diesel tanker truck & & 15 & 9.38 \\
\hline
\end{tabular}

\subsection{Estimated cost of operating machine}

The equipment rental price of the works public material company, served as the basis for determining the elementary hourly price of the following machines [11]. The public works equipment company is the only structure in the study area, which has a national scope and agencies in all departments of the country to respond quickly to the rental needs of companies. No other company has agencies everywhere. This is why the rental prices of the public works material company are known almost everywhere in the study area. Table 15 shows the rental rate of the public works material company from 2013 in Republic of Benin. And, Table 16 shows the hourly basic price of equipments. 
Table 15. Material rental rates (excluding taxes)

\begin{tabular}{|c|c|c|}
\hline Designations & $\begin{array}{c}\text { Hourly price } \\
\text { (USD) }\end{array}$ & $\begin{array}{c}\text { Daily price } \\
\text { (USD) }\end{array}$ \\
\hline Bulldozer CAT D7G & 91.28 & \\
\hline Bulldozer CAT D6D & 57.31 & \\
\hline Grader KOMATSU GD 623 A & 63.84 & \\
\hline Grader CAT 120B / Fiat G70G & 56.25 & \\
\hline Loader CAT 950 & 57.71 & \\
\hline Self-propelled compactor PS 300 & 42.88 & \\
\hline Self-propelled compactor PS 200 & 38.21 & \\
\hline Vibrating Compactor & 9.55 & \\
\hline Towed compactor & 24.41 & \\
\hline Road tractor RVI KERAX 380 & 41.64 & \\
\hline Road tractor RVI KERAX $380+$ RQ & 55.54 & \\
\hline Road tractor MITSUBISHI FV 415 & 33.28 & \\
\hline Road tractor MITSUBISHI FV $415+$ RQ & 47.17 & \\
\hline Towed compactor + agricultural tractor & 38.21 & \\
\hline Agricultural tractor & 13.80 & \\
\hline Agricultural tractor + agricultural trailer & 41.39 & \\
\hline Machine carrier trailer & 13.89 & \\
\hline Agricultural trailer & 27.60 & \\
\hline Dump truck $7 \mathrm{~m}^{3}$ & 23.98 & 96.49 \\
\hline Dump truck $5 \mathrm{~m}^{3}$ & 15.67 & 85.77 \\
\hline Truck point in time & 33.96 & \\
\hline Workshop truck & 38.21 & \\
\hline Truck crane & 27.60 & \\
\hline Tray truck & 22.29 & \\
\hline Service station truck & 31.84 & \\
\hline Tank Truck 10/12 $\mathrm{m}^{3}$ & 31.84 & 128.65 \\
\hline Tank Truck $6 \mathrm{~m}^{3}$ & 28.66 & 96.49 \\
\hline Mobile tank & 2.01 & \\
\hline
\end{tabular}


Table 15. (Continued)

\begin{tabular}{lcc}
\hline \multicolumn{1}{c}{ Designations } & $\begin{array}{c}\text { Hourly price } \\
\text { (USD) }\end{array}$ & $\begin{array}{c}\text { Daily price } \\
\text { (USD) }\end{array}$ \\
\hline Fuel Tank & & 23.22 \\
Motor Pump $30 \mathrm{~m}^{3} / \mathrm{h}$ & & 21.23 \\
Generator & 5.83 & \\
Compressor & 3.41 & \\
Factory Coated & 16.51 & 63.68 \\
Cement mixer 100L/300L & & 94.34 \\
Cement mixer 280L & & \\
\hline
\end{tabular}

Table 16. Hourly basic price of equipments

\begin{tabular}{lccc}
\hline \multicolumn{1}{c}{ Designations } & $\begin{array}{c}\text { Hourly price } \\
\text { (USD) }\end{array}$ & $\begin{array}{c}\text { Fuel } \\
\text { (USD) }\end{array}$ & $\begin{array}{c}\text { Basic price } \\
\text { (USD) }\end{array}$ \\
\hline Bulldozer CAT D7G & 91.28 & 21.89 & 113.17 \\
Bulldozer CAT D6D & 57.31 & 18.14 & 75.45 \\
Grader KOMATSU GD 623A & 63.84 & 18.14 & 81.98 \\
Grader CAT 120B / Fiat G70G & 56.25 & 13.76 & 70.01 \\
Loader CAT 950 & 57.71 & 13.76 & 71.47 \\
Self-propelled compactor PS 300 & 42.88 & 11.88 & 54.77 \\
Self-propelled compactor PS 200 & 38.21 & 11.88 & 50.09 \\
Vibrating compactor & 9.55 & 0.63 & 10.18 \\
Towed Compactor & 24.41 & & \\
Road tractor RVI KERAX 380 & 41.64 & 18.76 & 60.41 \\
Road tractor RVI KERAX 380 + RQ & 55.54 & 18.76 & 74.30 \\
Road tractor MITSUBISHI FV 415 & 33.28 & & \\
Road tractor MITSUBISHI FV 415 + RQ & 47.17 & 18.76 & 65.93 \\
Towed compactor + Agricultural tractor & 38.21 & & \\
Agricultural tractor & 13.80 & & \\
Agricultural tractor + Agricultural trailer & 41.39 & & \\
Machine carrier trailer & 13.89 & & \\
\hline
\end{tabular}


Table 16. (Continued)

\begin{tabular}{lccc}
\hline \multicolumn{1}{c}{ Designations } & $\begin{array}{c}\text { Hourly price } \\
\text { (USD) }\end{array}$ & $\begin{array}{c}\text { Fuel } \\
\text { (USD) }\end{array}$ & $\begin{array}{c}\text { Basic price } \\
\text { (USD) }\end{array}$ \\
\hline Agricultural trailer & 27.60 & & \\
Dump truck $7 \mathrm{~m}^{3}$ & 23.98 & 9.38 & 33.36 \\
Dump truck $5 \mathrm{~m}^{3}$ & 15.67 & 9.38 & 25.05 \\
Truck point in time & 33.96 & 9.38 & 43.34 \\
Workshop truck & 38.21 & 9.38 & 47.59 \\
Truck crane & 27.60 & 9.38 & 36.98 \\
Tray truck & 22.29 & 9.38 & 31.67 \\
Service station truck & 31.84 & 9.38 & 41.22 \\
Tank truck $10 / 12 \mathrm{~m}^{3}$ & 31.84 & 9.38 & 41.22 \\
Tank truck $6 \mathrm{~m}^{3}$ & & & \\
Mobile tank & 28.66 & 9.38 & 38.04 \\
Fuel tank & & & \\
Motor pump $30 \mathrm{~m}^{3} / \mathrm{h}$ & 2.01 & & \\
Generator & & & \\
Compressor & & & \\
Factory coated & & & \\
Cement mixer $100 \mathrm{~L} / 300 \mathrm{~L}$ & 5.83 & 2.50 & \\
Cement mixer $280 \mathrm{~L}$ & & & \\
\hline
\end{tabular}

\subsubsection{Determination of intermediate prices}

The development of unit prices requires the determination of certain prices, not contained in the tender documents, but which the informed entrepreneur calculates upstream because of their involvement in one or more prices of the price list [11]. These prices, not contained in the tender documents, are often called intermediate prices [11]. As intermediate prices, it can be quoted for example, the price of water returned on site and of the stacking of gravelly [11]. 
The production of the $12 \mathrm{~m}^{3}$ tanker truck is estimated at $12 \mathrm{~m}^{3}$ of water per hour for:

(1) an average transport distance equal to $15 \mathrm{~km}$;

(2) an average speed of $60 \mathrm{~km} / \mathrm{h}$;

(3) filling and watering time equal to 1 hour.

Thus, $1 \mathrm{~m}^{3}$ of water brought to the site is done in 0.08 hours such as shown in Table 3-17.

The stacking of lateritic gravels initially requires the stripping of top soil [7-11]. Thus, practical production for stacking lateritic gravels in the difficult conditions for bulldozer D7G cat blade $\mathrm{U}$ is equal to $45 \mathrm{~m}^{3} / \mathrm{h}$ or $360 \mathrm{~m}^{3}$ per day of 8 working hours. This gives 0.022 hours of work for $1 \mathrm{~m}^{3}$ of material such as shown in Table 18.

Concerning the supply of gravel over an average distance of $5 \mathrm{~km}$, the practical production of the 924-cat loader for a cycle time of $0.60 \mathrm{~min}$ in difficult conditions is equal to $55 \mathrm{~m}^{3} / \mathrm{h}$ or $440 \mathrm{~m}^{3}$ per $8 \mathrm{~h} /$ day [7-11].

In our case, it was estimated that a $7 \mathrm{~m}^{3}$ truck, over an average distance of transport equal to $5 \mathrm{~km}$, can in difficult conditions deliver two loads per hour. Which gives a practical production of $14 \mathrm{~m}^{3} / \mathrm{h}$ or $0.071 \mathrm{~h}$ for $1 \mathrm{~m}^{3}$ of material such as shown in Table 19 .

Table 17. Hourly cost price of equipments

\begin{tabular}{lcccc}
\hline Designations & Unit & $\begin{array}{c}\text { Quantity } \\
\left(\mathrm{m}^{3}\right)\end{array}$ & $\begin{array}{c}\text { Basic price } \\
\text { (USD) }\end{array}$ & $\begin{array}{c}\text { Cost price } \\
\text { (USD) }\end{array}$ \\
\hline $\begin{array}{l}12 \mathrm{~m}^{3} \text { water } \\
\text { tanker truck } \\
\text { Motor pump }\end{array}$ & $\mathrm{H}$ & 0.08 & 38.03 & 3.05 \\
$30 \mathrm{~m}^{3} / \mathrm{h}$ & $\mathrm{H}$ & 0.08 & 3.06 & 0.24 \\
Equipment cost price per $\mathrm{m}^{3}$ & & & 3.29 \\
\hline
\end{tabular}


Table 18. Cost price of equipment for stacking lateritic gravels

\begin{tabular}{ccccc}
\hline Designations & Unit & $\begin{array}{c}\text { Quantity } \\
\left(\mathrm{m}^{3}\right)\end{array}$ & $\begin{array}{c}\text { Basic price } \\
\text { (USD) }\end{array}$ & $\begin{array}{c}\text { Cost price } \\
\text { (USD) }\end{array}$ \\
\hline $\begin{array}{c}\text { Bulldozer D7G cat } \\
\text { blade U }\end{array}$ & $\mathrm{H}$ & 0.22 & 105.39 & 2.32 \\
Equipment cost price per $\mathrm{m}^{3}$ & & & 2.32 \\
\hline
\end{tabular}

Table 19. Cost price of the equipments following the supply of gravel over an average distance of $5 \mathrm{~km}$

\begin{tabular}{lcccc}
\hline Designations & Unit & $\begin{array}{c}\text { Quantity } \\
\left(\mathrm{m}^{3}\right)\end{array}$ & $\begin{array}{c}\text { Basic price } \\
\text { (USD) }\end{array}$ & $\begin{array}{c}\text { Cost price } \\
\text { (USD) }\end{array}$ \\
\hline $\begin{array}{l}\text { 924 cat loader } \\
\begin{array}{l}\text { ( } \mathrm{m}^{3} \text { dump } \\
\text { truck }\end{array}\end{array}$ & $\mathrm{H}$ & 0.018 & 66.58 & 1.20 \\
$\begin{array}{l}\text { Equipment cost price per } \mathrm{m}^{3} \\
\text { H }\end{array}$ & 0.071 & 30.28 & 2.15 \\
\hline
\end{tabular}

\subsubsection{Determination of unit prices}

Besides the site installation costs which are at a fixed price, the other tasks are paid at unit prices $[10,11]$. According to the designation of the tasks, the unit prices are calculated either on the basis of daily or hourly practical production or according to the intermediate prices initially calculated $[10,11]$.

With regard to the application price of the machines charged with backfill from borrowing showed in Table 20, this unit price is fully known from the intermediate prices. Regarding the light reprofiling of the road over $7 \mathrm{~m}$, the practical production of a $120 \mathrm{~B}$ grader is $0.629 \mathrm{~km} / \mathrm{h}$. Which gives $5 \mathrm{~km}$ per day of 8 hours of work. The application price shows in Table 21, is fully known from the intermediate prices. 
If for light reshaping, the grader did $5 \mathrm{~km} /$ day, it is assumed that for heavy reshaping, it will be $2.5 \mathrm{~km}$ per day. The $2.5 \mathrm{~km}$ of $0.1 \mathrm{~m}$ thick roadway gives $1.75 \mathrm{~m}^{3}$ of soil to compact. The PF300 compactor such as shown in Table 22, will do $10 \mathrm{~h}$ of time (production of PF300 $=171 \mathrm{~m}^{3} / \mathrm{h}$ ).

Table 20. Cost price of equipments of backfill from borrowing

\begin{tabular}{lcccc}
\hline \multicolumn{1}{c}{ Designations } & Unit & $\begin{array}{c}\text { Quantity } \\
\left(\mathrm{m}^{3}\right)\end{array}$ & $\begin{array}{c}\text { Basic price } \\
\text { (USD) }\end{array}$ & $\begin{array}{c}\text { Cost price } \\
\text { (USD) }\end{array}$ \\
\hline Stacking of the gravelly & $\mathrm{m}^{3}$ & 1.2 & 2.32 & 2.78 \\
Gravel supply & $\mathrm{m}^{3}$ & 1.2 & 3.35 & 4.02 \\
Backfill layer adjustment & $\mathrm{m}^{3}$ & 1.2 & 1.57 & 1.88 \\
Total & & & & 8.68 \\
Equipment cost price per $\mathrm{m}^{3}$ & & & & 8.68 \\
\hline
\end{tabular}

Table 21. Cost price of equipments of light resurfacing of the road over $7 \mathrm{~m}$

\begin{tabular}{lcccc}
\hline \multicolumn{1}{c}{ Designations } & Unit & Quantity & $\begin{array}{c}\text { Basic price } \\
\text { (USD) }\end{array}$ & $\begin{array}{c}\text { Cost price } \\
\text { (USD) }\end{array}$ \\
\hline Grader & H & 8 & 65.14 & 521.14 \\
Total & & & & 521.14 \\
Application price for unit & & & 104.23 \\
\hline
\end{tabular}


Table 22. Cost price of equipments of heavy resurfacing of the road over $7 \mathrm{~m}$

\begin{tabular}{lcccc}
\hline \multicolumn{1}{c}{ Designations } & Unit & Quantity & $\begin{array}{c}\text { Basic price } \\
\text { (USD) }\end{array}$ & $\begin{array}{c}\text { Cost price } \\
\text { (USD) }\end{array}$ \\
\hline Grader & $\mathrm{H}$ & 8 & 65.14 & 521.14 \\
PF300 Compactor & $\mathrm{H}$ & 10 & 50.66 & 506.56 \\
Water to bring on site & $\mathrm{m}^{3}$ & 175 & 3.29 & 575.04 \\
Cleaning of lateral ditches & $\mathrm{km}$ & 5 & 84.05 & 420.27 \\
Clearing divergent ditches & $\mathrm{ml}$ & 300 & 0.26 & 78.26 \\
Total & & & & 2101.27 \\
Application price for unit & & & & 840.51 \\
\hline
\end{tabular}

\subsection{Evaluation and choice of correction coefficients}

To show the importance of controlling the performance of equipment in road works, it will present two estimates from two different contractors. Firstly, a correction coefficient of 0.37 was applied to the theoretical production of the machines (Table 23), and secondly, a correction coefficient of 0.67 was applied to the theoretical production of the others machines (Table 24).

The second quote is more competitive than the first compared to its estimate. There was a significant difference of sixty-six thousand five hundred ninety-four point sixty-seven (66594.67) USD. With the first quote show in Table 23, to finish within the contractual period, it is important to double or triple the number of certain machines on the site, because of the low yield of machines which is applied. So, instead of two graders, it will need 3 to 4 graders to rent, which increases the cost of operating the machines, and will cause an impact on the financial offer during the tender. 
Table 23. Quote on the cost of material for the correction coefficient of 0.37

\begin{tabular}{|c|c|c|c|c|}
\hline Designation of work & Unit & Quantity & Unit price & Amount \\
\hline Installation costs & $\mathrm{ff}$ & 1 & 105208.75 & 105208.74 \\
\hline Clearance of right of way & $\mathrm{m}^{2}$ & 20000 & 0.04 & 882.69 \\
\hline Weeding & $\mathrm{m}^{2}$ & 13000 & 0.04 & 452.96 \\
\hline Clearance of work bed & $\mathrm{U}$ & 3 & 432.8 & 1298.39 \\
\hline $\begin{array}{l}\text { Demolition of reinforced concrete } \\
\text { structure }\end{array}$ & $\mathrm{m}^{3}$ & 44 & 22.89 & 1007.34 \\
\hline $\begin{array}{l}\text { Demolition of unreinforced concrete } \\
\text { structure }\end{array}$ & $\mathrm{m}^{3}$ & 12 & 22.89 & 274.73 \\
\hline Demolition of the masonry structure & $\mathrm{m}^{3}$ & 100 & 22.89 & 2289.41 \\
\hline Cleaning of the minor structure & $\mathrm{U}$ & & 0 & 0 \\
\hline Cleaning of gutters $0.8 \times 0.5$ to 1 & $\mathrm{ml}$ & & 0 & 0 \\
\hline Cleaning of lateral ditches & $\mathrm{km}$ & 10 & 1092.7 & 1092.7 \\
\hline Clearing of existing divergent ditches & $\mathrm{ml}$ & 1072 & 0.23 & 241.54 \\
\hline Clearing divergent ditches & $\mathrm{ml}$ & 2080 & 0.33 & 676.42 \\
\hline Creation of lateral ditches & $\mathrm{m}^{3}$ & 6600 & 0.33 & 2146.32 \\
\hline Rock breaking for ditch creation & $\mathrm{ml}$ & 20 & 9.86 & 197.12 \\
\hline Embankment from borrowing & $\mathrm{m}^{3}$ & 2000 & 11.29 & 22578.22 \\
\hline Backfill with cuttings from excavations & $\mathrm{m}^{3}$ & 0 & 0 & 0 \\
\hline Implementation of the wearing course & $\mathrm{m}^{3}$ & 8946 & 11.53 & 103153.53 \\
\hline Light reprofiling of the road over $7 \mathrm{~m}$ & $\mathrm{~km}$ & 3.15 & 135.49 & 426.81 \\
\hline Heavy reprofiling of the road over $7 \mathrm{~m}$ & $\mathrm{~km}$ & 1.85 & 1092.66 & 2021.43 \\
\hline Excavation & $\mathrm{m}^{3}$ & 0 & 0 & 0 \\
\hline Concrete of cleanliness & $\mathrm{m}^{2}$ & 0 & 0 & 0 \\
\hline Raft & $\mathrm{ml}$ & 0 & 0 & 0 \\
\hline Gutters from $0.8 \times 0.5$ to 0.8 & $\mathrm{ml}$ & 0 & 0 & 0 \\
\hline Gutters from $0.8 \times 0.8$ to 1 & $\mathrm{ml}$ & 215 & 22.88 & 4919.74 \\
\hline
\end{tabular}


Table 23. (Continued)

\begin{tabular}{|c|c|c|c|c|}
\hline Designation of work & Unit & Quantity & Unit price & Amount \\
\hline Gutters from $1 \times 1$ to 1.5 & $\mathrm{ml}$ & 650 & 31.74 & 20630.73 \\
\hline Cover slab (thickness $=15 \mathrm{~cm}$ ) & $\mathrm{m}^{2}$ & 200 & 1.73 & 345.64 \\
\hline Scupper $1 \mathrm{~m} \times 1 \mathrm{~m}$ & $\mathrm{ml}$ & 31.2 & 71.68 & 2236.45 \\
\hline Scupper $2 \mathrm{~m} \times 1 \mathrm{~m}$ & $\mathrm{ml}$ & 20.4 & 80.79 & 1648.05 \\
\hline Scupper $2 \mathrm{~m} \times 2 \mathrm{~m}$ & $\mathrm{ml}$ & 10.4 & 86.55 & 900.12 \\
\hline Backfill for access to structures & $\mathrm{m}^{3}$ & 1200 & 11.33 & 13599.89 \\
\hline $\begin{array}{l}\text { Upstream and downstream head for } \\
\text { scuppers } 1 \mathrm{~m} \times 1 \mathrm{~m}\end{array}$ & $\mathrm{U}$ & 3 & 28.82 & 86.45 \\
\hline $\begin{array}{l}\text { Upstream and downstream head for } \\
\text { scuppers } 2 \mathrm{~m} \times 1 \mathrm{~m}\end{array}$ & $\mathrm{U}$ & 2 & 48.03 & 96.05 \\
\hline $\begin{array}{l}\text { Upstream and downstream head for } \\
\text { scuppers } 2 \mathrm{~m} \times 2 \mathrm{~m}\end{array}$ & $\mathrm{U}$ & 1 & 110.46 & 110.46 \\
\hline Rubble masonry & $\mathrm{m}^{3}$ & 0 & 0 & 0 \\
\hline Rockfill & $\mathrm{m}^{3}$ & 0 & 0 & 0 \\
\hline Metal railings & $\mathrm{ml}$ & 0 & 0 & 0 \\
\hline Blackcurrant of slowing & $\mathrm{U}$ & 6 & 8.65 & 51.87 \\
\hline Type A 1000 traffic signs & $\mathrm{U}$ & 0 & 0 & 0 \\
\hline Type B 800 traffic signs & $\mathrm{U}$ & 0 & 0 & 0 \\
\hline Reinforced concrete beacons for turns & $\mathrm{U}$ & 0 & 0 & 0 \\
\hline $\begin{array}{l}\text { Reinforced concrete beacons for } \\
\text { structures }\end{array}$ & $\mathrm{U}$ & 24 & 0.15 & 3.68 \\
\hline Bounds kilometer penta & $\mathrm{U}$ & 0 & & \\
\hline Barrier of rain & $\mathrm{U}$ & 0 & & \\
\hline TOTAL & & & & 288577.48 \\
\hline
\end{tabular}


Table 24. Quote on the cost of material for the correction coefficient of 0.67

\begin{tabular}{|c|c|c|c|c|}
\hline Designation of work & Unit & Quantity & $\begin{array}{l}\text { Unit price } \\
\text { (USD) }\end{array}$ & $\begin{array}{c}\text { Amount } \\
\text { (USD) }\end{array}$ \\
\hline Installation costs & $\mathrm{ff}$ & 1 & 80929.8 & 80929.8 \\
\hline Clearance of right of way & $\mathrm{m}^{2}$ & 20000 & 0.03 & 678.99 \\
\hline Weeding & $\mathrm{m}^{2}$ & 13000 & 0.03 & 348.43 \\
\hline Clearance of work bed & $\mathrm{u}$ & 3 & 332.92 & 998.76 \\
\hline $\begin{array}{l}\text { Demolition of reinforced concrete } \\
\text { structure }\end{array}$ & $\mathrm{m}^{3}$ & 44 & 17.61 & 774.88 \\
\hline $\begin{array}{l}\text { Demolition of unreinforced concrete } \\
\text { structure }\end{array}$ & $\mathrm{m}^{3}$ & 12 & 17.61 & 211.33 \\
\hline Demolition of the masonry structure & $\mathrm{m}^{3}$ & 100 & 17.61 & 1761.09 \\
\hline Cleaning of the minor structure & $\mathrm{U}$ & & & \\
\hline Cleaning of gutters $0.8 \times 0.5$ to 1 & $\mathrm{ml}$ & & & \\
\hline Cleaning of lateral ditches & $\mathrm{km}$ & 10 & 84.05 & 840.54 \\
\hline Clearing of existing divergent ditches & $\mathrm{ml}$ & 1072 & 0.17 & 185.80 \\
\hline Clearing divergent ditches & $\mathrm{ml}$ & 2080 & 0.25 & 1646.02 \\
\hline Creation of lateral ditches & $\mathrm{m}^{3}$ & 6600 & 0.25 & 1651.02 \\
\hline Rock breaking for ditch creation & $\mathrm{ml}$ & 20 & 7.58 & 151.63 \\
\hline Embankment from borrowing & $\mathrm{m}^{3}$ & 2000 & 8.68 & 17367.86 \\
\hline Backfill with cuttings from excavations & $\mathrm{m}^{3}$ & 0 & & \\
\hline Implementation of the wearing course & $\mathrm{m}^{3}$ & 8946 & 8.87 & 79348.87 \\
\hline Light reprofiling of the road over $7 \mathrm{~m}$ & $\mathrm{~km}$ & 3.15 & 104.23 & 328.32 \\
\hline Heavy reprofiling of the road over $7 \mathrm{~m}$ & $\mathrm{~km}$ & 1.85 & 840.51 & 1554.94 \\
\hline Excavation & $\mathrm{m}^{3}$ & 0 & & \\
\hline Concrete of cleanliness & $\mathrm{m}^{2}$ & 0 & & \\
\hline Raft & $\mathrm{ml}$ & 0 & & \\
\hline Gutters from $0.8 \times 0.5$ to 0.8 & $\mathrm{ml}$ & 0 & & \\
\hline Gutters from $0.8 \times 0.8$ to 1 & $\mathrm{ml}$ & 215 & 17.60 & 3784.42 \\
\hline
\end{tabular}


Table 24. (Continued)

\begin{tabular}{|c|c|c|c|c|}
\hline Designation of work & Unit & Quantity & $\begin{array}{l}\text { Unit price } \\
\text { (USD) }\end{array}$ & $\begin{array}{l}\text { Amount } \\
\text { (USD) }\end{array}$ \\
\hline Gutters from $1 \times 1$ to 1.5 & $\mathrm{ml}$ & 650 & 24.42 & 15869.79 \\
\hline Cover slab $($ thickness $=15 \mathrm{~cm})$ & $\mathrm{m}^{2}$ & 200 & 1.33 & 265.88 \\
\hline Scupper $1 \mathrm{~m} \times 1 \mathrm{~m}$ & $\mathrm{ml}$ & 31,2 & 55.14 & 1720.35 \\
\hline Scupper $2 \mathrm{~m} \times 1 \mathrm{~m}$ & $\mathrm{ml}$ & 20,4 & 62.14 & 1267.73 \\
\hline Scupper $2 \mathrm{~m} \times 2 \mathrm{~m}$ & $\mathrm{ml}$ & 10.4 & 66.58 & 692.40 \\
\hline Backfill for access to structures & $\mathrm{m}^{3}$ & 1200 & 8.72 & 10461.46 \\
\hline $\begin{array}{l}\text { Upstream and downstream head for } \\
\text { scuppers } 1 \mathrm{~m} \times 1 \mathrm{~m}\end{array}$ & $\mathrm{U}$ & 3 & 22.17 & 66.50 \\
\hline $\begin{array}{l}\text { Upstream and downstream head for } \\
\text { scuppers } 2 \mathrm{~m} \times 1 \mathrm{~m}\end{array}$ & $\mathrm{U}$ & 2 & 36.94 & 73.88 \\
\hline $\begin{array}{l}\text { Upstream and downstream head for } \\
\text { scuppers } 2 \mathrm{~m} \times 2 \mathrm{~m}\end{array}$ & $\mathrm{U}$ & 1 & 84.97 & 84.97 \\
\hline Rubble masonry & $\mathrm{m}^{3}$ & 0 & & \\
\hline Rockfill & $\mathrm{m}^{3}$ & 0 & & \\
\hline Metal railings & $\mathrm{ml}$ & 0 & & \\
\hline Blackcurrant of slowing & $\mathrm{U}$ & 6 & 6.65 & 39.90 \\
\hline Type A 1000 traffic signs & $\mathrm{U}$ & 0 & & \\
\hline Type B 800 traffic signs & $\mathrm{U}$ & 0 & & \\
\hline Reinforced concrete beacons for turns & $\mathrm{U}$ & 0 & & \\
\hline $\begin{array}{l}\text { Reinforced concrete beacons for } \\
\text { structures }\end{array}$ & $\mathrm{U}$ & 24 & 0.12 & 2.83 \\
\hline Bounds kilometer penta & $\mathrm{U}$ & 0 & & \\
\hline Barrier of rain & $\mathrm{U}$ & 0 & & \\
\hline TOTAL & & & & 221982.68 \\
\hline
\end{tabular}


If, for example, two graders are maintained, as in the case of the second quote, poor quality work will be done within the contractual period. The second quote (Table 24) is competitive, and with this quote, not only will tenders always be won, but also will make the investment profitable. This demonstrates the importance of controlling the performance of machines for road works.

In addition to economic reasons, and the delay in the works, the non performance of the machines can lead to a poor improvement of the soil. Hence, checking the quality of the machines is necessary during the construction of the pavements in order to succeed, not only a good improvement of the soil, but also for a good performance of the structures.

Furthermore, the machines are progressively accumulated into technological progress, as much for their power and their precision as for their safety and the comfort of their operators. This has made even more spectacular achievements possible in all fields (land, maritime ...) and in all climates.

Since, on arable soils, the passage of heavy machinery often causes compaction, it is important to take care of everything related to the condition and the quality of the machines during the construction works or during the improvement of the soil. Based on the results, the theoretical productions of the machines must be corrected by appropriate factors linked to the conditions under which the works will be executed. Consequently, for a reassuring determination of the operating cost of the machines, this research proposes also considers, if the machines to be used, are not new or not performant, then consider if the machines will work in difficult conditions using as a correction coefficient 0.37. But, if the machines are new or performant, then consider a correction coefficient 0.67 . 


\section{Conclusion}

This research in no way pretends to have identified the whole outline of the problems linked to the control of the performance of the machines and to the estimation of their operating cost. But this research proposes a method which certainly deserves to be refined further to assist companies specializing in road construction, to avoid the underestimation of bid prices (dumping) and the bad organization of earth road worksites.

Machines and materials hold an essential place in public works since the construction boom and changes in the dynamics of production and machinery for road works are correlated. With the demand for new roads and the development of new habitats which continue to increase, the need for roadworks equipment becomes important. For a rational use of the machines on a road construction site, their choice must be based on a excellent knowledge of the methods of construction of pavement.

To attain all soil improvements, the contractor or the engineer in civil engineering must surround himself with reassuring guarantees to avoid situational offers that do not consider the realities related to the execution of the works. This is why the present research has reported a certain number of tables and formulas that make it possible to estimate the machines' production with the works' execution conditions. A reassuring determination of the equipment's operating cost suggests to small and medium-sized enterprises in the road sector who want to try their hand in this area to consider that the machines to be used will work even under challenging conditions. The machines' theoretical productions must be corrected by an appropriate correction coefficient linked to the conditions under which the works will be executed. Therefore, this research is proposed as a proper correction coefficient of 0.37 , if the machines to be used are not new or are not performant. An appropriate correction coefficient of 0.67 if the machines to be used is new or are performant. Certain endogenous factors could influence this correction coefficient 0.37 and lead the civil engineer contractor to make adjustments. 
Moreover, during the works' execution, the contractor or civil engineer may also use the tables that specify the degree of influence of the machines' factors of production to check if his calculations agree with the realities of the site. This will contribute to controlling the works in their evolution and the correct keeping of the analytical accounts. The part of research in no way pretends to have identified the whole outline of the problems linked to the control of the machines' performance and the estimation of their operating cost. But this research proposes a method that certainly deserves to be refined further to avoid companies specializing in road construction underestimating bid prices (dumping), and the bad organization of earth road worksites. If this approach finds a favourable response, it could be improved by more knowledgeable and published specialists to allow its implementation by small and medium enterprises. This will contribute to their promotion, and as soon as they have mastered the techniques of building earth roads, the study area in the tropical areas state will also have to gain because the competition space would be more enlarged. As a corollary, it would not fail to influence the very high costs of inevitable roadworks. To this end, and with a view to sustainable development, the following suggestions could be studied by decision-makers:

(1) Training or retraining of contractors or/and civil engineers on an earth road construction site's organization. This training will be seen in terms of programming, mobilization, and rational use of equipment, since most business leaders do not prioritize the investment of their resources in staff training;

(2) The organization of an experience exchange workshop in the field of material management between, contractors, mechanicians, equipment rental companies and representatives of contracting authorities;

(3) The organization of brainstorming sessions on ways and means can encourage local businesses to take an interest in construction or the rehabilitation of paved roads. 


\section{References}

[1] A. W. Dhowian and T. B. Edil, Consolidation behavior of Peats, Geotechnical Testing Journal 3(3) (1980), 105-114.

DOI: https://doi.org/10.1520/GTJ10881J

[2] S. Draber, Method for Determining Reliability Characteristics for a Technical Installation, United States Patent US 6,065,133. (2000) May 16.

[3] P. Neff, I.-D. Ghiba, A. Madeo, L. Placidi and G. Rosi, A unifying perspective: The relaxed linear micromorphic continuum, Continuum Mechanics and Thermodynamics 26(5) (2014), 639-681.

DOI: https://doi.org/10.1007/s00161-013-0322-9

[4] H. M. Alinaitwe, J. A. Mwakali and B. Hansson, Factors affecting the productivity of building craftsmen-studies of Uganda, Journal of Civil Engineering and Management 13(3) (2007), 169-176.

[5] R. L. Peurifoy, R. L. Peurifoy, R. L. Peurifoy, et al. Construction planning, equipment, and methods, Construction Management 13 (2010), 68-71.

[6] R. Cordell, Caterpillar Performance Handbook, 18@+(th) Edition, Caterpillar, Inc., Peoria, IL, 1987.

[7] E. C. Orlemann, Caterpillar Chronicle: History of the Greatest Earthmovers, MotorBooks International, 2000.

[8] L. Setra, Guide Technique, Réalisation des Remblais et des Couches de Forme, Guides du LCPC, 2000.

[9] M. Fall, F. Faye and A. Mbodji, Current knowledge and research on the design of flexible pavements in Senegal, Electronic Journal of Geotechnical Engineering 7 (2002), 1.

[10] F. N. Abdeen and Y. G. Sandanayake, Facilities management supply chain: Functions, flows and relationships, Procedia Manufacturing 17 (2018), 1104-1111.

DOI: https://doi.org/10.1016/j.promfg.2018.10.074

[11] A. C. Maevis, Construction cost control by the owner, Journal of the Construction Division 106(4) (1980), 435-446. 